\title{
ONSTRUCTION OF RESISTANCE
DISCOURSE IN LATVIAN POST-SOVIET LITERATURE ABOUT DEPORTATIONS AND IMPRISONMENTS
}

\section{Eva Birzniece}

University of Latvia, E-Mail: eva.birzniece@gmail.com

\section{Acknowledgments}

This paper has been presented at the Third International Conference on Nordic and Baltic Studies in Romania: European Networks: the Balkans, Scandinavia and the Baltic World in a Time of Crisis hosted by the Romanian Association for Baltic and Nordic Studies and Valahia University of Târgoviste, and sponsored by the Romanian National Research Council, May 25-27, 2012.

\begin{abstract}
:
During the Soviet era there were no publicly available published literary representations of the Soviet deportations and imprisonment of civilians and Latvian Army officers to Siberia and the Far East. If there were any, these were very scarce and available to very few people. Deportations and imprisonments were marginalized and silenced themes in all possible respects - politically, socially and culturally. Many narratives (in books published in state publishing houses) emerged only in the beginning of the 1990ies when the Soviet Union collapsed and Latvia regained its independence. Those narratives were written secretly during the Soviet time, as the authors were or could be repressed for talking about forbidden topics. The female experience was not only totally silenced but it was also different from men's experience of imprisonments and deportations as men and women with children were separated - men were sent to forced labour camps and women to places of settlement. Even when writing about deportations was dangerous, the narratives of that experience construct strong resistance to the Soviet repressions against Latvia and its people. Many female narratives about these experiences emerged later adding to the testimonials studies of archives and historical documents thus making resistance discourse more pointed and stronger.
\end{abstract}




\section{Rezumat:}

In perioada sovietică nu au existat reprezentări literare publicate cu privire la deportările sovietice și la întemnițarea civililor şi ofițterilor Armatei Letone în Siberia și în Orientul Îndepărtat. Dacă au existat totuși, acestea au fost foarte puține și au fost accesibile unui număr redus de persoane. Deportările și intemnițarea au fost teme marginalizate și reduse la tăcere în toate privințele - din punct de vedere politic, social și cultural. Multe relatări (din cărți publicate la editurile de stat) au apărut abia la începutul anilor '90 când Uniunea Sovietică s-a prăbușit și Letonia și-a recâștigat independența. Aceste relatări au fost scrise în secret in perioada sovietică deoarece autorii au avut sau ar fi putut să aibă de suferit prin abordarea unor teme interzise. Nararea experiențelor feminine nu numai că a fost supusă unei interdicții stricte, dar experiențele acestora au fost și diferite faț̆ de ceea cu au trăit bărbații deoarece femeile și copiii au fost separați de bărbați - acesstia din urmă au fost trimiși în lagăre de muncă forțată iar femeile în locuri de colonizare. Chiar şi să scrii despre deportări era periculos, relatarea acestor experiențe putând crea germenii unei puternice rezistențe față de represiunile sovietice impotriva Letoniei și a poporului său. Numeroase relatări feminine cu privire la aceste experiențe au apărut mai târziu adăugându-se mărturiilor din arhive și documentelor istorice, făcând astfel discursul cu privire la rezistență mai tăios și mai puternic.

Keywords: Post-Soviet Latvia; Soviet Latvia, silenced experience; female narratives; Baltic deportations; Soviet repression; women in the USSR, resistance

During the Soviet period in Latvia (and throughout the Soviet Union and elsewhere in the Soviet bloc) there were practically no literary representations of the mass deportations and imprisonments of army officers, former government members, intelligentsia and other civilians of Latvia. People of the Baltic countries (Latvia, Lithuania and Estonia) were sent to Siberia, Far North and other parts of the Soviet Union in big numbers, where many of them suffered from intolerable life and work conditions and died. Literary representations of this time and experience of the deported and imprisoned people appeared publicly only when the Soviet Union collapsed in the beginning of the 1990ies as some of them were written secretly during the Soviet era. The female experience of deportations and imprisonments had been totally silenced and marginalized; the women voices were made totally subaltern; without any form or media of representation. 
The number of the narratives of these experiences has grown steadily in Latvia. These memories create a very strong discourse of resistance to what was done to the nations by the communist regime of the Soviet Union and its leaders, but those narratives that were written during the Soviet times are especially valuable as they were created at a time when talking about the crimes of the Soviet rule was not mainstream and the authors could be severely prosecuted for documenting these facts and experiences. So, these authors were truly resisting when they wrote and risked imprisonment or exile.

The hypothesis of this article is that the narratives about deportations and imprisonments construct not only a discourse of witness, as some Latvians literary critics have previously suggested, but also a strong discourse of resistance. Strict censorship and political control during the Soviet period made it impossible to publish discussions or representations of the crimes of the regime in the sanctioned manner. The resistance in the three analyzed narratives is manifest in several ways: first, just by the fact of voicing and writing down the female experience of deportations, second, by very strong loyalty to the lost independent Republic of Latvia, its statehood, social and cultural values, third, by strong will and ability to survive regardless of anything, thus, creating a survival myth now and fourth, by expression of female solidarity and fifth, by condemning, even though secretly and indirectly, the crimes committed by the Soviet regime against people of Latvia. The methods used for this article are textual and biographical analyses.

\section{The Soviet deportations and imprisonments in Latvia}

The ostensible aim of the 1941 deportations was to reduce (expected) resistance to Soviet rule in Latvia. The intelligentsia was especially targeted. Although there had been considerable political repression in Latvia since 1940 when the Soviet Union occupied and incorporated Latvia into the USSR (from July, 1940, until May, 1941, on average about 250 - 300 people were arrested monthly), the scale and unprecedented political violence of the mass deportations of June 14, 1941, was totally new to Latvia. During the deportation of June 14, 15443 people 
in Latvia were apprehended and sent to unknown places. ${ }^{1}$ No charges were presented at the time of arrest and people were not informed what awaited them. This prevented many of the deportees from taking even necessary things like food, to survive the long journey, and warm clothing, to survive the cold winters in Siberia or the Far North, as they did not know that they had been formally charged and might be sent away for a long period. Sometimes people were prevented from taking their personal belongings by the people who came to arrest them. The people were taken to railway stations where men were separated from women and children. Often they were lied to and told that they would meet at the destination. Most of them never met again in their lives as very many were either killed in Gulag camps or died in interment. The apprehended people were put into cattle cars that had been modified (for carrying people) by hammering two berths, one above the other, on both ends of the stock-car and by cutting a hole in the car floor to be used as a toilet. The area in the middle was left empty. Around 40 - 70 people were put into each car. The conditions were unsuitable for human travel and totally unsanitary. "The procedure of the apprehension and transportation to Russia showed that the deported were no longer considered to be normal members of society."2 The horror of this deportation and arrests of the Year of Terror is often cited as the reason so many Latvian citizens fled to the West (Around 200 000 people left seeking refuge in countries outside of the direct control of the USSR) in 1944.

The second mass deportation took place on March 25, 1949. The deportations of 1949 were carried out to diminish resistance to collectivization (forced merging of individual farmsteads in big and state run collective farms that are called kolkhoz in Russian) and decrease support for the national resistance movement (partisan movement) of armed people hiding in the forests of Latvia. Thus, in the second deportation more rural inhabitants were affected than in the first one. More than 13000 families and a total of $\mathbf{4 2} 125$ people were deported from Latvia in March of 1949.3 More than 200 children were born on the way to

\footnotetext{
1 Daina Bleiere and Jānis Riekstinšs, The First Mass Deportation of the Inhabitants of Latvia. June 14, 1941 (Riga: Latvian State Archive, 2007a), 8.

2 Ibid.

${ }^{3}$ Daina Bleiere and Jānis Riekstinšs, The Second Mass Deportation of the Inhabitants of Latvia. March 25, 1949 (Riga: Nordik/Latvian State Archive, 2007b), 6.
}

178 
the settlements or later same year; 513 people were deported later as they had hidden on the night of March 25, but they were found later. The deportations of 1949 affected three times more people than the deportations of 1941. A total of $2.2 \%$ of the population were deported in 1949 as compared to $0.79 \%$ of the total population of Latvia on June 14, $1941 .{ }^{4}$

\section{A silenced and marginalized theme}

During the Soviet period in Latvia (1940 -1991), very few spoke of the fact of deportation and the life of the deported people in their settlements and imprisonment in the Gulag camps. Equally, few of the returning deportees spoke openly about their lives when they began returning to Latvia in the mid 1950ies.

For more than 50 years this was a censored, marginalized and silenced part of the history and literature in all possible respects: politically, socially and also culturally. There was virtually no literary dissident movement in Latvia during the Soviet era, as all resistance movements and acts were very severely persecuted by the Soviets and controlled through use of persistent threat of imprisonment. This led to fear and silence.

When the Soviet Union was about to collapse at the end of the 1980ies and the beginning of the 1990ies, several stories about deportations and imprisonments were published by state publishing houses in Latvia, thus starting the wave of memory narratives about the themes that had been previously totally erased from the public discourse. Women's and men's narratives depicted a different experience, as women had a unique experience as they and children had been separated from men in the first deportation of 1941. Men were generally imprisoned and sent to the Gulag camps while women were placed in settlements and were not formally charged. Since then, autobiographical narratives about the experience of the deportations have become very popular in Latvia. Their genres include novels, autobiographies, memoirs, and documentary and historical novels. The narratives written in the independent Republic of Latvia (reestablished in 1990) definitely have a different perspective from those written during the Soviet times: they have the advantage of hindsight. Those written in the post 1990s era have the luxury of looking back at the history from a different point; when all of the threats and limitations (that

4 Bleiere and Riekstinsš 2007a, 17. 
there were during the Soviet times) had been removed. They also are written from a distant perspective that is different from an immediate account of the events in the same historic era when they had taken place. So they may be reporting what the author would have liked to have thought or done rather than what the author actually thought or did.

This article is an empirically founded analysis of two sets of narratives about the deportations and imprisonments. The first set consists of two narratives- the autobiographical novels "Velzupes krastā" (On the Banks of Dead Soul River), 1991, by a former journalist and later prolific writer Melānija Vanaga, and "Ekshumācija" (Exhumation), 1990, by the writer Anita Liepa. Both of these books were written, but not published, during the Soviet era in Latvia. The second set in this analysis is a book written in the post-Soviet period - the documentary novel "With Dance Shoes in Siberian Snows", 2001, by the independence movement activist and politician Sandra Kalniete. In contrast to the previous two pieces, this narrative was strongly influenced by the political and social situation of, then, only recently renewed Republic of Latvia. Vanaga and Liepa's works are defined by the need to write secretly and to document history and reality that had been erased from the public memory. "With Dance Shoes in Siberian Snows" is the most widely translated literary work of modern Latvian literature; so far it has been translated into 11 languages while the novels "On the Banks of Velupe" and "Exhumation" have not yet been translated. The excerpts quoted in this article are from the English translation of the novel "With Dance Shoes in Siberian Snows" translated by Margita Gailitis and published by The Association of the Occupation Museum of Latvia in 2006.

\section{Female pre and Post-Soviet narratives about deportations and imprisonments}

The novels "On the Banks of Velupe" and "Exhumation" both are survivor stories, as they depict the real-life experiences (while in deportation or in prison) of the narrators, Further, they report the experience of their close family members and testimonials of other survivors. Both novels were written long before Latvia regained its independence in 1991, but were not published because of strong censorship. Both authors were very conscious that if their writing were discovered, it would be dangerous for them and their families. 
The prominent Latvian independence movement leader, diplomat and politician Sandra Kalniete published her documentary novel "With Dance Shoes in Siberian Snows" in 2001 in Riga. She was born in Togur, in Siberia, in 1952. Her parents were deportees who met and married while they lived in the settlement. It is the first documentary novel about the deportations to Siberia that not only recounts personal experience (of Kalniete's family members on both parental sides) but gives a vast factual material about Latvia's pre-Second World War history with SovietGerman-Soviet occupations. It further considers the context for the ways Latvians reacted to the dramatic events as they did. Kalniete was the first author of autobiography to combine family memory with archival materials in order to reconstruct what happened to her family and the whole nation.

Anita Liepa, the author of "Exhumation", in the afterword of her novel says that the version published in 1990 was the fifth manuscript of the novel. The first one was destroyed by relatives. The second manuscript of the novel was found by the Soviet authorities.

Following the discovery, she was accused of anti-Soviet propaganda, was tried and sentenced to imprisonment according to Paragraph 58 as a criminal. Some contemporaries claim (her study mate and literary critic Biruta Gudrikse) that Anita Liepa was sentenced because of her anti-Soviet activities, one of her deeds being spitting from a balcony at a high Communist Party functionary of Latvia. Anita Liepa served her sentence (released in May 11, 1956) in women's prison in the Far North, in Archangelsk Oblast. This experience is reflected in the later variants of the novel that combines both her beloved uncle's Anatolijs Sondors' imprisonment in a Gulag camp and then, later, the protagonist's attempts to find her uncle's grave that leads to her being imprisoned herself as an enemy of the Soviet system. It took Anita Liepa 45 years to write the novel.

Anita Liepa is believed to have documented a strike in Norilsk that she saw when she visited a Latvian community of formerly imprisoned Latvian Army officers. She was there looking for the grave and traces of her uncle Anatolijs Sondors, a Latvian Army officer, who had been deported from the Latvian Army summer camp in Litene to the Gulag in 1941 where he died shortly thereafter. Both story lines, the quest for the trace of a beloved uncle vanished anonymously in the Gulag, and the narrator's personal experience as a political prisoner of the Soviet rule, intertwine. 
As Sandra Meškova says, Anita Liepa's "Exhumation" initiated the post-Soviet autobiographical tradition. ${ }^{5}$ The novel gives a broad overview of Latvian history in the $20^{\text {th }}$ century and chronologically links the lifestories of four generations of the Sondors family. The novel focuses on the second generation, mainly on Anatolijs Sondors whose life is determined by the events of the consequent Soviet and German occupations in 1940 and 1941 respectively, the consequences of which are faced by the third and fourth generations represented by Sondor's foster daughter Nameda.

Anatolijs Sondor's career in the Latvian Army was terminated by the Soviet occupation and, together with many other Latvian Army officers, he was sent to prison in 1941 where he died in 1944. The novel further turns to his foster-daughter Nameda who tries to find out the truth about his death and learn where he was buried. Sandra Meškova says that "Under the conditions of Soviet regime, this was a heroic attempt at searching for truth, resisting the official ideology, and opposing the oblivion imposed on the pre-Soviet period of Latvian history." 6

\section{Women who did not forget}

The very fact of speaking about and remembering what had happened in Latvia in 1940-1941 and consequently in the later years in Liepa's novel "Exhumation" is an act of resistance. Liepa says in her interview with a literary critic and her study mate Biruta Gudrikse "I became a witness for the defense of my heroes to be rehabilitated. Now there are others who write about those events. I began writing when no one else dared. "7

Liepa uses the metaphor of exhumation for remembering, locating and bringing a deceased relative home - at least to public memory if not the official history - those who have been forgotten not only by the officials but also by their kin and people. Even close family members of the deportees did not mention this experience to their children. Sandra Kalniete, whose parents were deported and later met and got married in a settlement, did not hear about these facts as a child: "In my childhood, the past was only mentioned in connection with household incidents and

\footnotetext{
5 Sandra Meškova, "Reconstructing History in Latvian Post-Soviet Autobiographical Writing," Darbai ir dienos (Kaunas: Vytauto Didžiojo universitetas, 2010), 146.

6 Ibid., 146.

7 Biruta Gudriķe, „Anita Liepa un viņas romāni,“ in Jaunākā latviešu literatūra 1998 (Rīga: Zvaigzne ABC, 1999), 99. Translated by Sandra Meškova.
}

182 
family events, but almost never in its political or historic significance. I grew up under the influence of Soviet propaganda, knowing almost nothing about the real history of Latvia. The latter was totally buried in silence. This self-imposed censorship mirrors the desire of my parents not to complicate the life of their child with unanswerable questions and dangerous doubts. Above all, they wanted to protect me from a repetition of their own tragic fate." 8 People kept quiet about the fact and ordeals of deportations so as not to hurt themselves, as many of these memories made the survivors feel humiliated and ostracized, and to protect their children from knowing.

The Latvian literary scholar, professor of University of Latvia, Ausma Cimdina in her review of the novel "Ekshumācija" in 1990 appreciates the courage and responsibility of Anita Liepa to talk about deportations and imprisonments very highly. She believes that the very fact of telling the parts of the history of Latvia and its people that professional historians and writers had totally avoided is a reason to respect and admire the novel by Liepa. ${ }^{9}$ When reviewing the novel a Latvian writer and literary critique Guntis Berelis is of the totally opposite opinion. To him the novel "Exhumation" seems too delayed in time; he believes that the right time to speak about the Soviet repressions and the harm it had inflicted on the society and individuals in Latvia had (at the time of the review) already passed and those who did not have the courage to speak about these events at least a few years before the collapse of the Soviet Union should not do it in 1990.10

The literary process in Latvia after 1990 has shown exactly the opposite trend when more and more people both professional writers and just survivors have written their memories about the deportations of 1941 and 1949 and imprisonments of civilians into Gulag labour camps.

Another Latvian writer and literary critic Visvaldis Lāms in 1990 values Liepa's novel very highly because of its emotional intensity and the urgency to remember what happened to and in Latvian families during the Soviet times. He sees the symbolic and thus main value in the narrator's

\footnotetext{
8 Sandra Kalniete, With Dance Shoes in Siberian Snows (Riga: Latvijas Okupācijas muzeja biedrïba, 2006), 105.

9 Ausma Cimdiṇa, „Svešvārdi un jaunvārdi: ekshumācija, mitomānija." Literatūra un Māksla 6 (1990).

10 Guntis Berelis, „Romāns pret dokumentu“ Karogs 7 (1990): 177.
} 
determined attempts to link the silenced past and people lost in it with the present and people living now. ${ }^{11}$

Melānija Vanaga, the author of "On the Banks of Velupe," returned from Siberia in 1957, after spending 16 years in a forced settlement. Vanaga did not start writing her memories right away; it took her some years to gather strength to do it. The author said in an interview in 1995: "During the kolkhoz time I did not write about Latvia so as not to hurt my heart that still had not healed properly. People were also simply forbidden to write even about a flower or a cat". ${ }^{12}$ After returning from Siberia, Vanaga worked as a shepherd in the kolkhoz that was established incorporating land and building property that had belonged to her family. She started writing her memories about the settlement and asked her friends in Riga, who were Communist party members, to hide her manuscript to hopefully assure that it would not be found by the Soviet authorities.

Another aspect of resistance, apart from just voicing the deportation and imprisonment experience, is loyalty to and appreciation of the lost independent Republic of Latvia, its statehood, its social and cultural environment. The narrator in "On the Banks of Velupe" is loyal to the independent Republic of Latvia where she worked as a professional journalist with her husband Aleksandrs Vanags, also a journalist and editor-in-chief for the newspaper "Daugavas Vēstnesis", before being imprisoned in 1941. Vanaga cherishes the democratic and cultural values, people, traditions, nature and work ethic of the lost, independent Latvia. Her whole family including her husband and a teenage son was deported to Siberia in 1941. The husband was separated from her and the son and he was sent to a prison. Vanaga herself remained with their teenage son. The responsibility to take care of the young child was one of the cornerstones of her will to survive in the settlement at any cost.

The son became an adult very quickly, as he had to work to provide subsistence for himself and the mother. He had to learn the Russian language in a few days to be able to work. At times the mother and the teenage son are separated as the mother has to shepherd animals from one farm to another for very long distances. She leaves the son for several days alone in their hut with very little food. The boy has to manage his life and he always does. When the mother returns from the "trip", she finds her son

\footnotetext{
11 Visvaldis Lāms, „Mūžam mūsējie," Karogs 7 (1990): 177.

12 Vija Jugāne, „Par brīvību un pienākumu,” Karogs 7-8 (1995): 15-22 (My translation - E.B.). 184
} 
well and determined to do what he has to do: "What this time has been like for Alnis, you ask? The good days have been few, and the bad ones he is reluctant to talk about, as he's been raised not to complain of others or of the hardships suffered, since his boyhood." ${ }^{13}$

Vanaga describes the everyday fight for survival in great detail. Her narrative incorporates the testimonials of several other deportees. She collected these stories during her 16 years of settlement in Siberia; they are sometimes difficult to distinguish one from another and it is sometimes difficult to discern whose voice is talking as the testimonials are very similar. The testimonial modality provides the necessary level of generalization of the female experience where individual stories merge into a collective story of not only suffering and loss but also a strong manifestation for will to survive.

The testimonies and the recitation of the details of the daily fight for survival in the settlement are in sharp contrast to the memories of the organized and safe life in the (pre-Soviet) Republic of Latvia. The narrator's heart bleeds for her destroyed life and the lives of the people around her, for the other Latvian women, people of other nationalities who were repressed and deported (Germans, Jews, Estonians, Lithuanians, Kalmyks) but especially for the young children who died in massive numbers en route as they could not tolerate conditions of the journey to Siberia and then later in the cold, famine and hardships of the settlement in Siberia. She sees that lives of the deported children and youth are taken away from them without ever having been lived. Vanaga herself regrets not having repatriated from Latvia to Germany in 1939 when she and her family could have done that on the basis of the German family line in her husband's family.

Even though the image of the pre-war Latvia is often constructed as a Paradise, the memories of the civilized and law abiding life in Latvia are the source of strength and endurance for the deported teenager daughter Ligita and her mother Emilija in Sandra Kalniete's novel "With Dance Shoes in Siberian Snows". The dream of experiencing everyday pleasures like going to a seamstress and a manicurist and cultural experience of

13 Melānija Vanaga, Vel̦upes krastā (Rīga: Liesma, 1991), 62. (The excerpt translated by Aija Uzulēna) 
attending opera, keep the daughter and mother going in the cold, starvation and hardship of the settlement.

A strong indicator of resistance at both individual and collective level was the change in the identity of the Latvian women as compared to their personal integrity and typical selves in Latvia before the deportations. The deported women had to take up any job just to survive; some of them had to learn Russian overnight (as many Latvians did not speak Russian) to be able to have a job and provide for themselves and their children. The narratives construct the identity of very strong and capable women who take care of their own and their children's lives. The deported women show rationality and extreme will to survive in intolerable and unfair conditions. Vanaga in the novel "On the Banks of Velupe" describes a case when a woman en route to Siberia becomes desperate and kills her three young children and later tries to kill herself. This act is stopped and condemned by other Latvian women; they try to do anything to save their and their children's lives. Their will to survive is extraordinary in the face of the ordeals they have to experience.

Compared to the local inhabitants of the places of deportations and wardens in the prisons, Latvian women were literate and generally welleducated, and education becomes their entrance ticket to best qualified jobs in displacement and also a source of social status at least in the local Latvian community which remained very important all through the deportation and imprisonment time. The experience and self-reflection of the Latvian women fall into what an American literary scholar David Chiony Moore in his article "Is the Post- in Postcolonial the Post- in PostSoviet? Toward a Global Postcolonial Critique?" defined as reversecolonization. He argues that many Central and Eastern European countries economically, culturally and socially felt superior the "colonizing" Soviet Union and thus comparison between the quality of life and living standard was always in favour of the "colonized" countries. ${ }^{14}$

The Latvian women narratives very often refer to the poor and neglected villages, houses, households and children of the places of

14 David Chioni Moore, "Is the Post- in Postcolonial the Post- in Post-Soviet?", in Toward a Global Postcolonial Critique. Baltic Postcolonialism, ed. Violeta Kelertas (Amsterdam/New York, NY: Radopi, 2006).

Cited from "Postkoloniālais un postsociālistiskais: pretruna vai iespēja?" , Aktuālas problèmas literatūras zinātnēe (Liepāja: Liepājas Universitātes Literatūras katedra, 2009), 122. 
settlements. In contrast with the miserable living conditions of the settlements, they take pride in taking good care of their children, their homes, ability to cook, sew and knit, also their literacy and education. The first impressions of the Soviet countryside shock the deportees as everything looks different from the Soviet propaganda picture of Russia. Sandra Kanliete's grandmother recalls:

"How the landscape changed beyond the border of Latvia! Lopsided huts. Unkempt fields. Run-down, emaciated farm animals. So this is what the Soviet Union looked like! Ho very much it differed from what they had heard in the first year of the Soviet regime about the joyous and free Soviet people, who lived happily in a prosperous land of plenty under the wise leadership of Stalin.15"

The clothes, footwear and a few household items taken from Latvia serve as means of exchange in the first years of the deportations. Women exchange these for food to survive or for winter clothing and boots that very many of the deported people do not have with them. The metaphor for the clash of civilized and cultured environment the deported Latvians came from with the crudeness of life and climatic conditions is very clearly expressed in the title of the book "With Dance Shoes in Siberian Snows" by Sandra Kalniete. The dance shoes turn out to be the only footwear Kalniete's mother Ligita had with her when she was deported to Siberia and they were totally unsuitable for conditions there.

Sometimes the deported women have to get involved in immoral behaviour like stealing food from the fields of collective farms just to stay alive. The women do that realizing both that it is a crime but at the same their only way to not to die of starvation. The fight to stay alive is the first and dominant form of resistance as all the deported or imprisoned people know that the aim of their deportation is to exterminate them; they see so much brutal and ruthless deaths around them. The recounts of what happens to a human body that has lived in starvation, cold and unsanitary conditions for a long time and not getting any medical help when needed are horrifying. Sandra Kalniete's grandmother Emilija several times fights for her teenage daughter Ligita to stay alive:

${ }^{15}$ Kalniete, 63. 


\begin{abstract}
"Emilija looked on powerlessly as her child slowly wasted away. In Bilina, Ligita's splendid blonde hair was cut off, leaving only a symbolic strand of hair on her forehead. Her bald head had broken out in boils oozing puss. Head lice, showing off their shiny well-fed behinds, fed in the boils as if they were bowls of meat. In Petropavlovska, Ligita fell ill with malaria, which was a terminal illness for her body wasted away by long-term starvation. Emilija only had a damp cloth at her disposal to use as a cooling compress to put on her daughter's forehead while she lay half-conscious with starvation and malaria. Emilija herself was only skin and bones, but she took morsel of food from herself and gave it away to her daughter."16
\end{abstract}

Familial and female solidarity in general is very strong in these narratives about the deportations and imprisonment. The American Estonian scholar Tiina Kirss describes gender differentiation of deportations and consequent difference in men and women's experiences: "The way the 1941 deportations were carried out throughout the forcible separation of families intensified the gender-differentiation of the experience, at least for adults. What awaited men was the struggle for individual survival, in the context of the solidarity of their countrymen and fellow camp inmates; women sent to remote Siberian villages had dependent children and the elderly to care for in semi-starvation conditions, as labourers, providers, and nurturers." 17

The protagonist in "Exhumation" was courageous enough to question and, thus, oppose the wardens in the female prison about some of their decisions like making women work outside in extreme cold or work extra hours. The wardens took these questions as a challenge; that later led to open confrontations and strikes in the prison. The imprisoned women stayed united even in the face of repressions from the prison administration:

Then comes a moment when their measure of patience turns out to be spent. After the signal to call off work, women begin to make for

\footnotetext{
16 Ibid., 164.

17 Tiina Kirss, „Survivorship and the Eastern Exile: Estonian Women's Life Narratives of the 1941 and Siberian Deportations," Journal of Baltic Studies XXXVI, no. 1 (Spring 2005): 13. 188
} 
the door. They are Lithuanians, Latvians. Estonians remain seated. The taskmaster, blocking the exit, attempts to stop them. The convicts just brush her aside. She grabs Nameda by the hand. 'You won't go, will you? A rational woman like you, diploma and everything... You know how nasty this ends.' Nameda releases her hand and quietly passes her in the door-way. But the gate to the living zone is closed. They wouldn't open it without the nod of the taskmaster. The time is early spring, so it's windy and cold. ... and they spend a good hour standing at the gate and banging the fence with their fists. Nameda remembers a strike in women's prison in Norilsk. 'We should shout, - she says, - shout out loud all as one.' A unison tide of scream washes across the fence stopping the bypassers who freely walk the street outside the internment-camp. Some of them could have their wife, daughter or sister locked in. Immediately, a crowd forms at the guard-entrance demanding the platoon commander to come outside. What do you have going on there? What is it your KGB guys make those women suffer? How can you just stand here and listen them scream like that?18

The imprisoned women started shouting and their shouts were heard on the street. This frightened the wardens and they let the women finish their workday on time. But the resistance of the women was punished and after the second time of protesting the illegally prolonged work day in the prison some women disappeared, and some, like Nameda, became seriously ill because of utter distress and tension.

Other examples of female solidarity in the prison are the prisoners informing each other about a spy among them, helping each other to do their daily norm of work that is undoable for the weaker women and also sharing their dreams and premonitions about each other's future. Thus, a Lithuanian girl called Terēza tells Nameda the place of her uncle's grave and an exact date when she would be released from the prison. A Latgalian girl Stefānija has exactly the same dream at the same time about release of Nameda from the prison. Both dreams become absolute truth, as Nameda is freed exactly on the day forecast by Terēze and she also finds the place where Latvian officers are buried. Premonitions are a strong part of female

18 Anita Liepa, Ekshumācija (Rīga: Liesma, 1990), 427 (The excerpt translated by Aija Uzulēna.). 
lives, because with the help of dreams and visions they connect to each other emotionally and spiritually, the forms of which are very limited in the Soviet prisons.

Women's drive to survive and resistance to the humiliating life conditions is expressed also in appreciation of the Siberian nature and attempts to start their own home, or at least a household, even in the poverty of Siberia thus providing their own living space. This was a way for the deported women to be responsible and try to regain control over their own lives at least to some extent.

The attempt of Latvians to take control of their own lives and improve it is manifest in helping each other to survive by sharing space to live and especially in extreme situations, for example, when somebody was ill or a woman need help with burying her children. The protagonist of "On the Banks of Velupe" takes in a terminally ill former Latvian Gulag prisoner Âdolfs just to let him die at home, not in the local hospital with no family or at least other Latvians around. This makes the sick man feel less desperate when dying without knowing what had happened to his relatives in Latvia and being unable to inform them about his fate.

Vanaga's house becomes a meeting point of other Latvians in the settlement where they could be on their own, share their feelings, talk, help each other and host a guest who needs a space unobserved by local people that are seen as strangers and often also hostile:

\begin{abstract}
"What we called our Little Hotel was no place of insurgent secret meetings of any kind. It was simply that I was the least well off of all and anywhere far was closed for me. And I had my own shed which, without disturbing any Russians, you could come to visit or spend a night in better than in any other Latvian woman's place in a borrowed space, and more so since I already had Ādolfs living with me no longer able to go anywhere at all. And so the Latvians used to come to us either to lend a hand around the house or to share in the common adversity of our fate. " 19
\end{abstract}

Vanaga starts a new house several times in the settlement even though financially it always is almost impossible. Having her own house

19 Vanaga, 241 (The excerpt translated by Aija Uzulēna). 
where she can be her own master and at times host other Latvians and striving for her son Alnis to get education are two red threads through the whole memoir of the life in Siberia.

\section{Conclusions}

Regardless of the strong female identity and discourse of resistance created in the narratives about the deportation, there are several themes that remained silenced. These include gender crimes against women, collaboration of Latvians with the Soviet functionaries who deported people and later, after the deportees returned from Siberia, system functionaries who kept penalizing and co-citizens who ostracized the deportees.

The Latvian-British anthropologist Vieda Skultans studied formal prosecution protocols in the KGB archives in Riga about deportations in the mid 1990ies and then later, found and listened to oral testimonies of some of the same people whose protocols she had studied. She concludes that, through constructing deportation narratives, people gain agency to represent their very humiliating and destructive experience of deportations and imprisonments in a liveable way. They do it by inserting significant details and reshaping the story. Through telling their stories about deportations and imprisonment, people have the power that they did not have at the time when they were persecuted and no decisions concerning their lives were dependent on them. Creating a story about what happened is a way to shape it in a liveable and dignified way. ${ }^{20}$

To some extent this is clearly visible in the narratives about deportations of Latvian women authors. The books written during the Soviet times, but not published then, show a greater level of individual and local community resistance to the deportations and soviet rule, while the novel by Sandra Kalniete adds to the individual and community resistance a broad European and Latvian history context where discourse of resistance becomes even stronger. Sandra Kalniete, of course, has the privilege of hindsight but it and the availability of the historic sources (archives and testimonials of her family members) add very substantially to what her predecessors have done relying only on their survivor experience and the testimonials of others.

20 Vieda Skultans, "Arguing with the KGB Archives. Archival and Narrative Memory in Post-Soviet Latvia," Ethnos 66, no. 3 (2001): 320. 
The narratives about deportations, whether created during the soviet times or in post-Soviet decades, create a strong resistance discourse starting from individual woman's decision to do anything in order to be able return to Latvia to the politically and factually detailed explanation of the genesis of occupations, war, Latvia losing its statehood in 1940 and consequent deportations and imprisonments in 1941 and 1949. The uniting modality of these narratives is that what was done to people of Latvia by the Soviet rule was not right and people have resisted in the ways available to them at the time - through constructing the narratives and memories and keeping them alive through the time when all dissident attitudes were strictly prohibited. 


\section{References:}

\section{A. Books:}

Bleiere, Daina and Jānis Riekstinšs. The First Mass Deportation of the Inhabitants of Latvia. June 14, 1941. Riga: Latvian State Archive, 2007. Bleiere, Daina and Jānis Riekstinšs. The Second Mass Deportation of the Inhabitants of Latvia. March 25, 1949. Riga: Nordik/Latvian State Archive, 2007.

Liepa, Anita. Ekshumācija. Rīga: „Liesma”, 1990.

Kalniete, Sandra. With Dance Shoes in Siberian Snows. Riga: Latvijas Okupācijas muzeja biedrība, 2006.

Vanaga, Melānija. Veļupes krastā. Rīga: “Liesma”, 1991.

\section{B. Articles:}

Berelis, Guntis. „Romāns pret dokumentu.“ Karogs 7 (1990).

Cimdiña, Ausma. "Svešvārdi un jaunvārdi: ekshumācija, mitomānija." Literatūra un Māksla 6 (1990).

Moore, David Chioni. „Is the Post- in Postcolonial the Post- in Post-Soviet? Toward a Global Postcolonial Critique. Baltic Postcolonialism.“ Ed. Violeta Kelertas. Amsterdam/New York, NY: Radopi, 2006.

Gudriķe, Biruta. "Anita Liepa un vinas romāni.“ In Jaunākā latviešu literatūra 1998. Rīga: Zvaigzne ABC, 1999, 97-105.

Jugāne, Vija. „Par brīvību un pienākumu.” Karogs 7-8 (1995): 15-22.

Kirss, Tiina. "Survivorship and the Eastern Exile: Estonian Women's Life Narratives of the 1941 and Siberian Deportations." Journal of Baltic Studies XXXVI, No. 1 (Spring 2005).

Lāms, Visvaldis. „Mūžam mūsējie.” Karogs 7 (1990).

Meškova, Sandra. „Reconstructing History in Latvian Post-Soviet Autobiographical Writing." Darbai ir dienos (Kaunas: Vytauto Didžiojo universitetas, 2010): 143-156.

Skultans, Vieda. "Arguing with the KGB Archives. Archival and Narrative Memory in Post-Soviet Latvia." Ethnos 66, No. 3 (2001): 320-343. 